\title{
Integration of Architecture Concept of Tsunami Disaster Response With the Image Area Concept on the Coastal Area (Case Study : Serangan Island, Denpasar, Indonesia)
}

\author{
I Gede Surya Darmawan ${ }^{*}$, I Wayan Wirya Sastrawan² \\ Architecture Department, Universitas Warmadewa, Denpasar, Bali-Indonesia \\ \{suryadarmawan@warmadewa.ac.id¹,wirya@warmadewa.ac.id²
}

\begin{abstract}
Serangan Island is the only one of the largest reclamation in Bali which until now still exists as one of the favorite tourist destinations in Denpasar because of the island's location with an international airport, complete infrastructure and coastal tourism attractions that Serangan Island offers. On the other hand, Serangan Island is predicted to be one of the areas with the threat of an earthquake accompanied by a tsunami because the island is located in the ring of fire and the island's topography is relatively parallel to sea level. This research will examine the extent to which the tsunami disaster response architectural concept has been applied to the coastal area of Serangan Island and is integrated with the image area concept, and hope that Serangan Island remains one of the favorite tourist destinations in Denpasar while still providing a sense of security for tourists. This study uses a qualitative phenomenological approach, data collection techniques by observation and interviews, the results of which are associated with relevant theories for interpretation which results in research conclusions.
\end{abstract}

Keywords: Tsunami Disaster Reponse; Image Area Concept; Coastal Area; Reclamation

\section{Introduction}

Indonesia, which consists of a group of islands, has a very high potential for natural disasters such as earthquakes, tsunamis, and volcanic eruptions. Moreover, Indonesia is on the most active earthquake path in the world because it is surrounded by the Pacific Ring of Fire and is on top of three piles of continental plates, namely Indo-Australia from the South, Eurasia from the North, and the Pacific from the East. In the past year alone, there have been at least 3 devastating earthquakes, namely in Lombok, Central Sulawesi and East Java and 2 times the tsunami disaster, namely in Central Sulawesi and the Sunda Strait which killed more than 3,000 people and hundreds of thousands of people lost their homes (Hasanah).

Reflecting on the series of natural disasters, it is necessary to have disaster mitigation in each region in the form of an arrangement and planning in handling it, which is carried out in a directed and integrated manner. The countermeasures that have been carried out so far have not been based on systematic and planned steps, so that often overlaps occur and there are even important steps that are not handled. Law Number 24 of 2007 concerning Disaster 
Management mandates articles 35 and 36 so that every region in disaster management efforts has a disaster management plan.

Serangan Island is one of the tourist destinations in Bali which is the result of reclamation in 1995-1998, famous with the image of the area as "Turtle Island" because it is the center of turtle breeding grounds. In addition, the image of the Serangan Island area has been formed due to the existence of one of the Dhang Khayangan temples in Bali which once every six months invites thousands of Hindus across Bali and Indonesia to pray at Sakenan Temple. Apart from that, beach and marine tourism, watersports, coral reef cultivation and seaweed, and the presence of Bugis and Bali fishing villages add to the tourist attraction of Serangan Island. Moreover, with the construction of a bridge connecting Bali Island and Serangan Island in 1998, it is very easy for tourists to go to Serangan Island. In addition, the construction of an Eco Resort in the form of a museum, a center for creativity, hotels, villas, a marina area, and a turtle-shaped opera house that was built in the middle of the sea starting in 2018 will certainly attract more local and foreign tourists to visit Serangan Island (Bali).

In fact, behind the many tourism potentials, it turns out that Serangan Island has the threat of an earthquake and tsunami because the island is located on the south coast facing the Indian Ocean and the island's topography and land elevation is relatively low, which is only 1-2 meters high above sea level. vulnerable to being submerged in sea water. In addition, several hundred kilometers south of Serangan Island lies one of the main tectonic stack zones on Earth (the Indo-Australian Plate), which is the main source area for earthquakes with a potential tsunami. Geologists and tsunami experts consider Serangan Island as one of the high risk areas for a tsunami hazard in Denpasar City in the future, because every major tsunami that reaches Serangan Island will have a severe impact on its population and tourism development (Sutarja).

In 2014, the Provincial Government of Bali through the Regional Disaster Management Agency (BPBD) built a communal space in the form of a Temporary Evacuation Site (TES) which is integrated with the Serangan Island market with financial assistance from the National Disaster Management Agency (BNPB). As is known, the TES building stands on land reclaimed by the sea by the investor PT. Bali Turtle Island Development (BTID) and has been handed over to become the ownership and management of Pakraman Serangan Village in 1998, through an agreement stated in the Momerandum of Understanding (MoU) dated October 14, 1998, to become the center of economic activity on Serangan Island in the form of a Village Market (Darmawan). This building is the only building to respond to the earthquake and tsunami disaster on Serangan Island. Based on this, the author will try to identify and integrate the concept of disaster response architecture with the concept of the image of the area in the coastal area by taking a case study of the coastal area of Serangan Island.

\section{Literature Review}

In the context of disaster response architecture in spatial planning and settlement, there are several important concepts, including (Sukawi, 2008):

\subsection{Escape Route}

Apart from earthquake-resistant buildings, what is needed in an effort to minimize the impact generated by a disaster is planning the evacuation route for disaster victims. Basically 
there are 2 types of evacuation route planning, namely evacuation routes in buildings and evacuation routes in residential areas.

a. Evacuation Routes in Buildings

Planning for escape routes in buildings, especially those with floors, is mostly done by making emergency stairs or lists that can be directly connected to the outer space. Usually the emergency stairs are placed on the side of the building or right in the middle which is the core of the building. This is intended to make access to and from the building easier and safer.

b. Evacuation Routes in Housing / Settlements

In planning a settlement, it should be considered regarding the service line planning system / environmental services. Because this system is a design of the flow of movement of service vehicles (such as garbage collectors, goods carriers, fire engines including ambulances) from a particular neighborhood block or plot, which is mapped to the hierarchy / class of roads that exist in the planning area. This is important because if a disaster occurs, as much as possible the rescue vehicle can immediately go to the location to provide assistance. Identify a rescue flow in the event of a disaster :

- Availability of pedestrian paths to higher areas. The road for the evacuation route.

- Construction of multi-storey building structures, must pay attention to better evacuation routes (for example: emergency stairs outside the building).

- Disaster-based spatial planning that has prepared itself with places and evacuation routes if floods or fires or other disasters occur.

- Disaster-based spatial planning that has prepared itself with places and evacuation routes in the event of a flood or fire or other disaster.

\subsection{Protected Area}

Protected areas are one of the important aspects in the concept of spatial planning and the environment for disaster response. The identification that is included in the protected area, among others :

- Provision of safe zones in residential areas.

- Planning of support structures (embankments, mangroves, etc.).

- Planning for productive buffer zones (ponds, rice fields).

- Layered green line planning to filter debris / garbage in case of flooding.

- Nature conservation as part of the buffer zone. No deforestation. In residential areas, which are densely populated with buildings, so that the level of water infiltration into the ground is reduced, with insufficient catchment areas not available. If there is rain with high rainfall, some of the rainwater becomes surface water which has the potential to cause flooding.

\subsection{Safe Zone}

In planning that functions as a settlement, it must be considered everything related to building and environmental planning. This is intended so that the arrangement of the housing environment can be more optimal. In addition, with this arrangement, a clear mapping of land use will also be created. One of the things included in the building and environmental planning that needs efforts if it is linked in the case of a disaster, is the existence of a disaster safe zone. A safe zone can be in the form of open space in a residential area which in fact functions as green land such as fields and forests. It can also be in the form of a safety building / evacuation in the event of a disaster, whose real function is building public facilities. 


\subsection{Open Space and Vegetation}

There is a boundary between the coastal area and the residential area which can reduce the level of sea water flows that enter during a disaster. One of the boundaries can be in the form of perennials (mangrove, nipah, waru, coconut). The beach is straight and protected by perennials, relatively good for settlement. The use of trees to absorb $\mathrm{CO} 2$ and reduce air temperature can reduce the use of air conditioning. Between the beach and the residential area planted with coastal trees that are strong and have dense leaf volume (for $\mathrm{CO} 2$ absorption).

The construction of open space (open space) and city parks can be maximized which later can be used as an emergency room for the city. The emergency room in the city is equipped with the need for clean water, KM / WC for defecating, communication equipment and a warehouse to store food and medicine for several days while waiting for help to come. So that we no longer hear the news of starving refugees and haven't eaten for 2 days or more because we haven't received any assistance.

Realizing a disaster response city can be done by increasing the vegetation in city parks which is a habitat for wild animals such as birds and other insects which can also serve as an early warning against disasters. We need to learn a lot from the people at the foot of Mount Merapi to develop sensitivity to natural changes marked by the behavior of wild animals.

\subsection{Public Facilities in Disaster Response Settlements}

In suburban areas, public facilities (shops, schools, community meetinghouses) serving residential areas are grouped close to houses that need them. So that residents do not need to drive their motorized vehicle to reach it. Meanwhile, in large cities, the polycentric (multicenter) layout of the city can reduce the mileage from the suburban area to the main functions (commercial, government center, etc.) located in the city center. Public facilities are placed at a safe distance and a central position from the housing so that they are easily accessible. Provided a number of public facility centers for a number of housing units it serves

The concept of disaster response architecture in this paper will be integrated with the concept of the image of the area with the aim that the case study which takes the location of the coastal area of Serangan Island provides a sense of security from the threat of disaster for tourists and local communities while still providing an even more attractive attraction and attracting more and more tourists. Therefore, the concept of area image is important as a theoretical basis. The concept of an image of an area is closely related to the identity of several elements in an area that are characterized and distinctive as identities that can differentiate from other cities [1]. An image of a city / region can be created instantly, while an identity takes a long time to form. The identity of the city / region is related to the historical rhythm that has gone through a long process so that the identity of a city cannot be created just as different from the image of the city. An image requires [2] : identity in an object or something that is different from others, the structure or pattern is interconnected between the object and the observer, and the object has meaning for the observer. The elements forming the image of the city / region are :

- Paths, is a path used by the observer to move or change places and becomes the main element because the observer moves through it when observing the city and along this path other environmental elements are arranged and connected.

- Edges, is a limit, it can be a design, a road, a river, a mountain. Edge has a strong identity because of its clear visuals. Edge is a barrier even though sometimes there is a place to enter which is the termination of a district or boundaries of a district with others.

- Districts, is a part of the city that has a special character or activity that can be 
recognized by its observers. Districts have distinctive patterns and forms as well as district boundaries so that people know the end or beginning of the area. District has the characteristics and characteristics of the area that is different from the surrounding area.

- Nodes, is a node or circle of strategic areas where the direction or activity meets each other and can be changed to another direction or activity, for example, traffic intersections, stations, airports, bridges, the city as a whole on a large macro scale, markets, parks, squares, a place rotational form of movement, and so on. A node is also a place where people have the feeling of 'coming in' and 'going out' in the same place.

- Landmark, is a visually appealing symbol with an attention-grabbing placement nature. Usually landmarks have a unique shape and there are different scales in their environment.

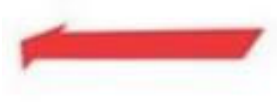

PATH

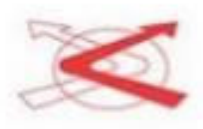

NODE

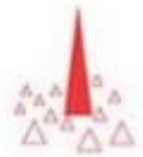

LANDMARK

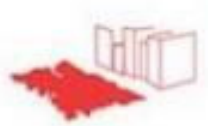

EDGE

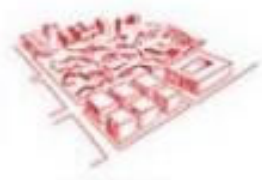

DISTRICT

Figure. 1. Five Elements Forming the Image of The Area

\section{Methods}

This study uses a descriptive qualitative approach that describes phenomena based on the informants' point of view, finds various realities and develops a holistic understanding of a phenomenon in a particular context [3]. A qualitative approach is generally used in describing inductively, with assumptions based on social reality, variables that are difficult to measure, complex and interrelated, and the data collected contains the in-depth viewpoints of the informants [4]. Through this approach, the researcher will present an as-is phenomenon that takes the theme of disaster in the world of architecture by taking a case study of one of the coastal tourism objects in Denpasar, Bali. Research instruments can be defined as the tools needed to collect data. In qualitative research, the main instrument in data collection is the researcher and other people who help the researcher. In this study, researchers collected data by asking, asking, listening, and taking [5]. The additional instruments needed by researchers in this study include: basic maps of coastal areas in Denpasar City, total station measuring instruments and laser meters, writing and drawing tools, computers with graphic specifications and cameras. The data collection method uses 4 techniques, namely the method of observation, in-depth interviews and questionnaires, documents and FGD (Creswell, 2007). The method of observation is by mapping coastal areas through the google earth application, drones, taking photos, videos, and sketches of important zones related to research in coastal areas. In-depth interview method using purposive sampling method, namely taking a sample of informants who are considered to have the most useful information, namely the Head of the Regional Disaster Management Agency (BPBD) Denpasar City, Village Heads, Beach Managers, and Business Actors. Document method by taking maps on google maps, journals, books and research-related writings. As well as the FGD method by conducting limited 
coordination meetings with several local stakeholders to get an overview of the integrated image of the area and the disaster mitigation efforts that have been implemented.

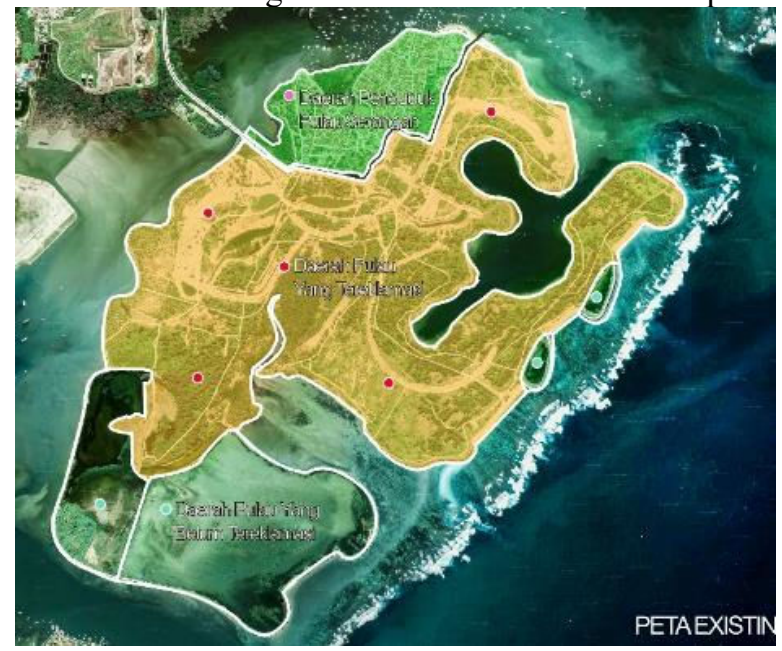

Figure. 2. Research Locations and Research Focus on Serangan Island

\section{Result and Discussions}

In applying the final objective of this research, namely the integration of the concept of disaster response architecture with the concept of regional image, the author will combine the two theories described above to be further analyzed through each of the theoretical approaches, in this case the disaster response architectural theory becomes the main theory while the image theory area becomes a supporter of the main theory to be integrated in the analysis.

\subsection{Escape Route}

Before identifying a rescue route in disaster mitigation efforts on Serangan Island, first identified the area of Serangan Island which is divided into three zoning prone to tsunami disasters, namely the area owned by PT. BTID, which is located to the right of the tourist canal, is categorized as an area that is quite risky and is very at risk of being exposed to the tsunami hazard because it is directly facing the open sea. Fortunately, this area consists mostly of empty, sandy land and overgrown with wild plants. Meanwhile, the residential areas to the left of the canal are considered safe areas at risk of being hit by a tsunami. This area consists of 7 Banjar Adat and Dinas and 1 Kampung Bugis. 


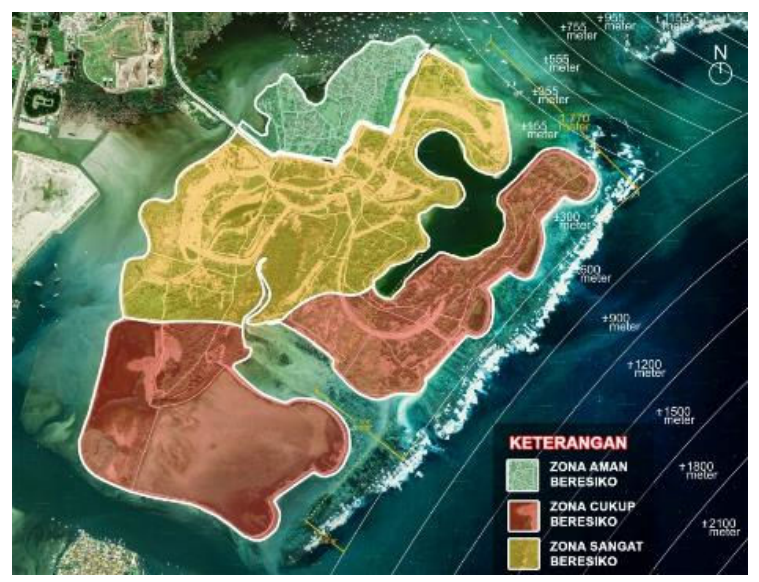

Figure. 3. Tsunami Prone Zoning Analysis

In the Resettlement area, which is likely to have the greatest impact in the event of an earthquake accompanied by a tsunami, there is only 14 -story building with a height of more than 12 meters (possibly around 12 meters), namely the Tsunami TES building which daily functions as a Village Market. Regarding the location of the Tsunami Market / TES building on Serangan Island, the evacuation route utilizing local roads has been well designed with a settlement pattern perpendicular to the coastal route. The people living in 7 banjars and 1 bugis village almost surround the TES tsunami building, so that in the event of a tsunami, the community can shorten the time they evacuate to the Tsunami Market / TES building. Meanwhile, the zoning for settlements close to Sakenan Temple can evacuate to the Tsunami TES building or to the safe zone, namely the Denpasar BKN Office which is on Jl. Ngurah Rai Bypass. However, considering the distance from the BKN Office, which is to cross the bridge connecting Bali Island and Serangan Island, it is possible that the residential areas on the south side are very vulnerable to being affected. Therefore, it is better to design evacuation facilities similar to TES Tsunami or to make use of existing buildings with adjustable height and sturdy structures against earthquake and tsunami attacks. In the existing residential area of Serangan Island, there is already a road that circles the resident area of Serangan Island. This indicates that there is a service line planning system for both the circulation of fire engines and ambulances. This is very important, especially when a disaster occurs, so that rescue vehicles can immediately go to the location and provide assistance and then get direct access outside Serangan Island by circling the residential areas. In addition, a circular road can be used as the main access for residents to evacuate to the Tsunami TES Building and quickly leave the Serangan Island. 


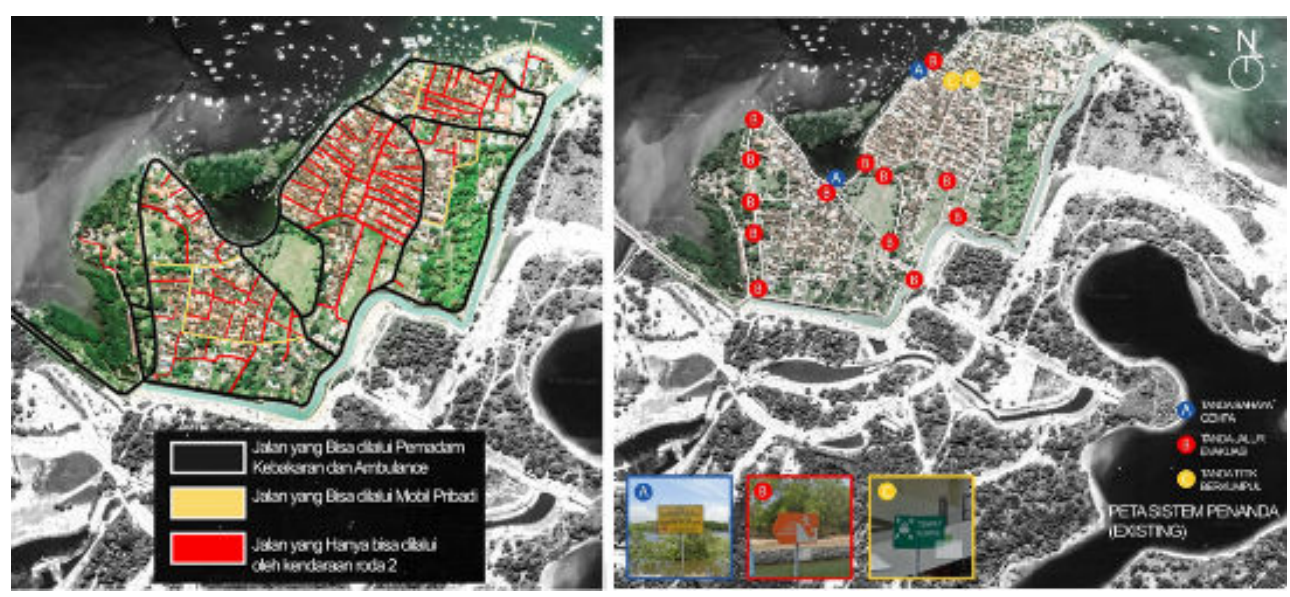

Figure. 4. Evacuation Routes and Existing Marking Systems

Even though there is already a ring road in residential areas, including a road shortcut in the middle with a road width that is approximately the same, in fact the ring road width is not completely the same, there are several circular road spots that have narrow road widths so the possibility of cars Fire and Ambulance have difficulty getting through this spot. In addition, in this spot, there are no pirates in front of the residents' houses. In addition, the absence of pedestrian paths makes pedestrians walk on the vehicle path everyday. Some of these spots are of course a concern and evaluation in making architectural planning concepts and disaster response areas

In several places on the coast of the island, both directly adjacent to the deep sea and shallow sea, earthquake and tsunami evacuation alerts have been installed. Coastal beaches which are directly adjacent to the deep sea, are installed with warning signs for areas prone to tidal sea water and tsunamis, while the coasts directly adjacent to shallow seas are attached warning signs for earthquake and tsunami evacuation. Serangan Island is connected to the Tsunami Early Warning System (InaTEWS). The earthquake and tsunami warnings will be disseminated via radio and television, loudspeakers at the mosque and notifying the seven Banjars on Serangan Island to sound the Kulkul. One of the Bale Kulkul is the one in Pura Dalem Cemara, precisely to the east of the TES tsunami building. Based on the distribution map of the location of the disaster alert system above, it can be concluded that the disaster alert system on Serangan Island is divided into 3, namely :

- An alert to leave the beach if you feel an earthquake. The location of this map is still minimal with a relatively small size (less than 1 meter long), with no clear information about the path to leave the beach.

- Alerts for disaster evacuation routes. The number of these markers is the largest here, but the location of these markers is very minimal on the east and south sides, with a relatively small size, but information and image illustrations have been well defined.

- Meeting place marker. Which is placed on the 2 front sides of the Tsunami TES Building, the dimensions are also relatively small (less than $50 \mathrm{~cm}$ long), but the illustrations and information are quite clear.

There are several things that are lacking in the context of disaster mitigation, especially in the absence of a special rescue route for pedestrians, so the researcher tries to make a recommendation for the design concept of pedestrian paths that surround residential areas. 
This pedestrian evacuation route is designed with the aim of not disturbing the circulation of vehicles, especially ambulances and fire engines in disaster mitigation efforts. The pedestrian path design concept is also equipped with a sign for the direction of evacuation to TES Tsunami and out of Serangan Island on the railing and floor. The pedestrian path design is designed to keep the elements of beauty in mind and support the aesthetics of the regional corridors through the use of wood materials on the railings and a combination of paving and brush stones on the pedestrians.

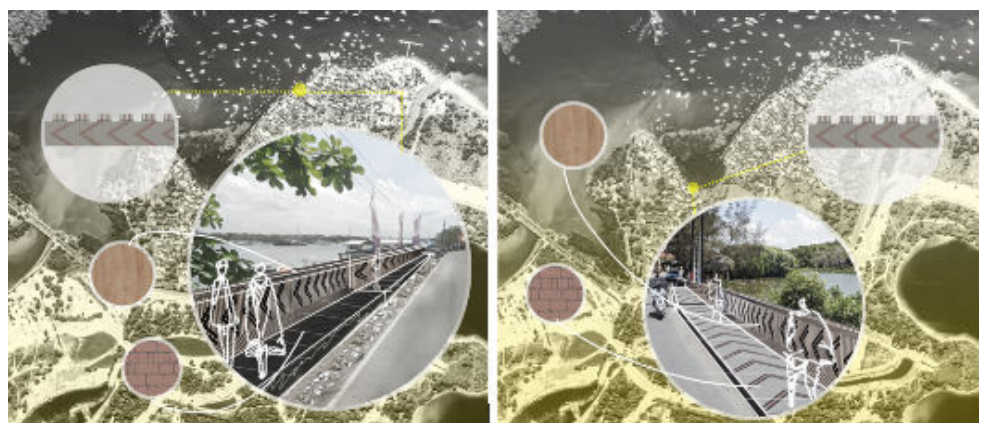

Figure. 5. Pedestrian Path View Concept for Evacuation to Safe Zone

\subsection{Protected Area}

Protected areas in the concept of architecture and disaster response environment consist of safe zones in residential areas, planning of buffer structures (retaining embankments, mangrove forests), planning of productive buffer zones (ponds, rice fields), planning layered green lines to filter debris / garbage in the event of flooding. , as well as nature conservation as part of the buffer zone. In Serangan Island, the implementation of a disaster protection area has been implemented although it needs to be maximized with better planning going forward. In terms of safe zone procurement, currently the residential area is still quite safe and ready for disaster mitigation because it is not directly adjacent to the high seas on the east and southeast sides, which in fact are empty land owned by investors. This vacant land is the reclamation result of PT. BTID, which until now has not been utilized. It is hoped that investors will not build massive facilities in the form of residential buildings on the offshore, namely on the East and Southeastern sides of Serangan Island because they are at the greatest risk of being affected in the event of a tsunami disaster. We recommend that you plant plants that function as green belts, for example mangroves.

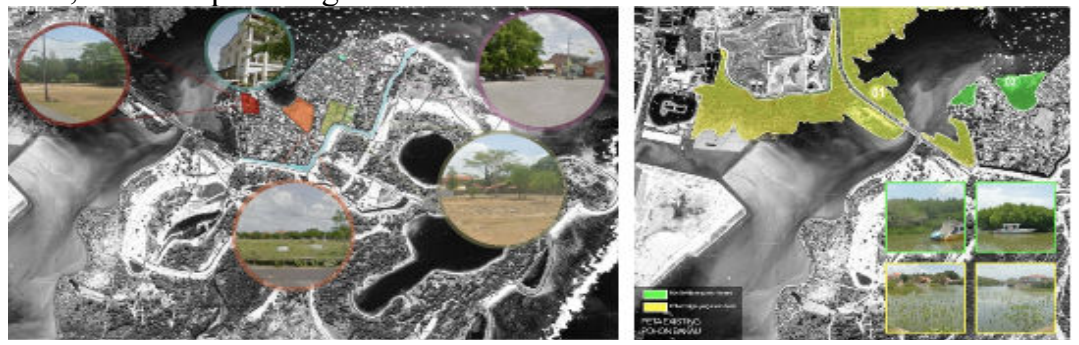

Figure. 6. The Integration of TES Tsunami with Outer Space and Mangrove Zoning That does not Pay Attention to The Aspects of Tsunami Disaster Mitigation 
Planning for buffer structures such as retaining embankments and mangrove forests in appropriate locations can also determine the disaster response of an area, apart from providing the area's thermal comfort and becoming the area's vocal point. In the area of Serangan Island, the placement of mangroves, both large and newly planted (still small) mangroves, is located in an inappropriate location, which is on the west side which is the opposite of the high seas which provide the potential for a tsunami, namely on the east and southeast sides. If the mangrove forest is used as a green belt, it should be placed in an area that is directly opposite to the open sea so that when the tsunami disaster occurs, mangrove trees can reduce / slow down the speed of tsunami waves towards the mainland residential areas. Of course, this gives more time for the community and tourists to immediately evacuate to the Tsunami TES or to the BKN Building which is outside Serangan Island.

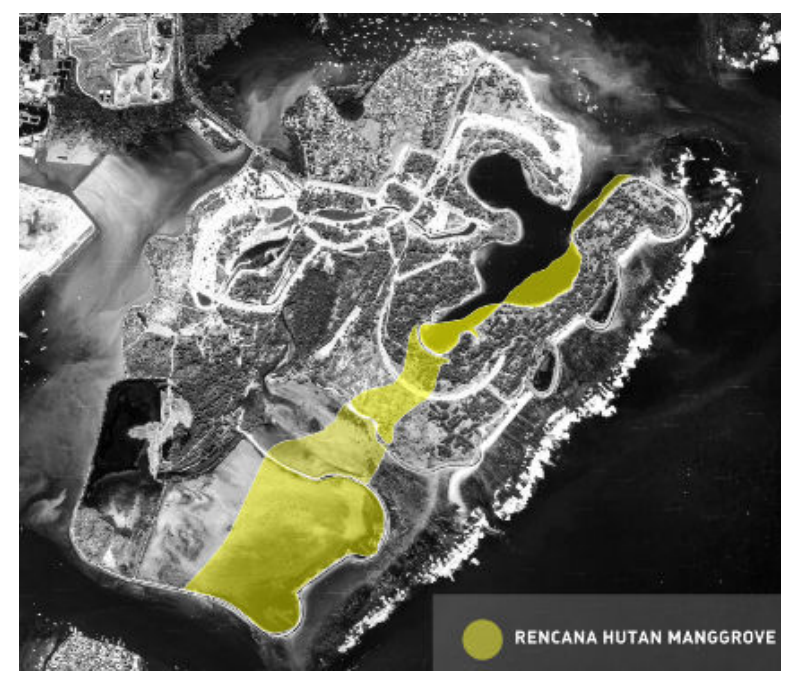

Figure. 7. The Mangrove Laying Concept Which Takes Into Account The Concept of Tsunami Disaster Mitigation

\subsection{Safe Zone}

The disaster safe zone is one of the important things in spatial planning and the disaster response environment. A safe zone can be in the form of open space in a residential area which in fact functions as green land such as fields and forests. It can also be in the form of a safety building / evacuation in the event of a disaster, whose real function is building public facilities. The placement of the Market building location as well as the Tsunami TEST has taken into account the scope of the area to be evacuated. If there is an indication of an earthquake that has the potential for a tsunami, at least the northern and eastern areas of Serangan Island which are directly adjacent to the sea can immediately evacuate to Tsunami Market / TES. In an emergency situation, at least residents of 5 banjars namely Banjar Ponjok, Kaja, Tengah, Kawan, Peken and Kampung Bugis can evacuate in this building. If time allows, of course, it is better to evacuate outside Serangan Island. 


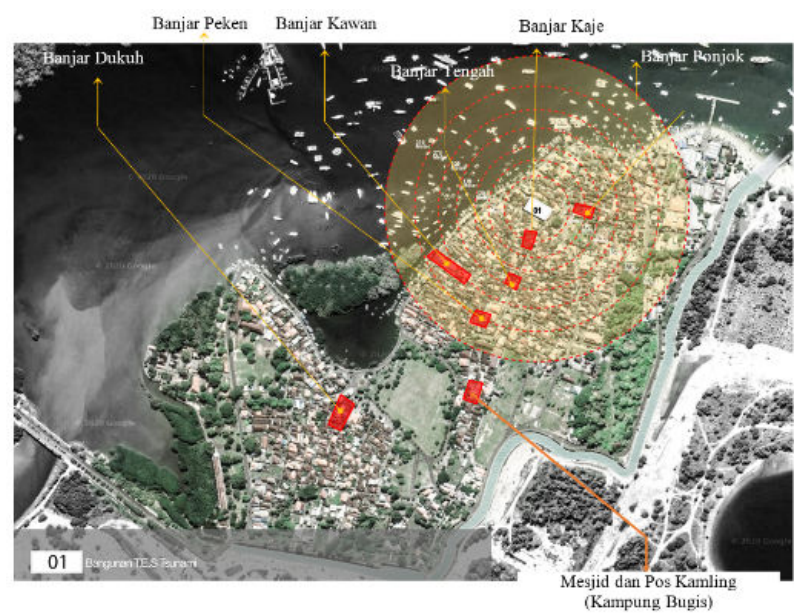

Figure. 8. Evacuation Area Coverage Radius from TES Tsunami

Based on the author's analysis based on the exposure to the TES Tsunami evacuation coverage map, it can be concluded that the residential areas of the Banjar Dukuh and Bugis Villages are not covered in the TES Tsunami radius area in the context of evacuation in an emergency, because they are far enough away so that it requires more time to evacuation. Of course, the residents in the TES Tsunami coverage area first fled to the building, so the author's suggestion is needed a similar development plan for the TES Tsunami in the Banjar Dukuh area which is of course used for public facilities on a daily basis.

Based on this, the authors make recommendations for the placement of a similar TES Tsunami in densely populated areas outside the existing TES Tsunami coverage radius. As previously stated, the ownership area on Serangan Island is divided into two, namely the residential area and the ownership area of PT. BTID. In residential areas where TES Tsunami already exists, it will be recommended to add similar buildings in the Banjar Dukuh area and Bugis Village. The recommended strategic place is SMP N 11 Denpasar. The choice of this place is based on a strategic location, and can be used daily as a place for student learning. While in the area of ownership of PT. BTID, considering the construction of tourist facilities, it is necessary to plan a TES Tsunami building at two locations so that tourists traveling in this place feel safe and can quickly evacuate to the nearest TES Tsunami when a tsunami disaster comes.
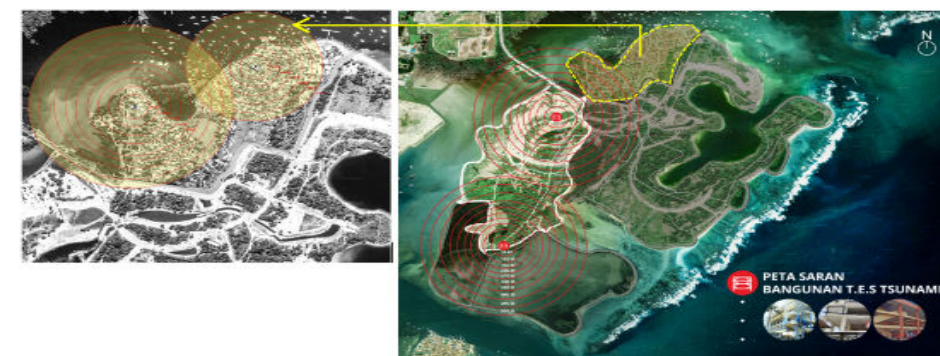

Figure 9. Recommendations for Placing The New TES Tsunami in Residential Areas and Areas Owned by investors 


\subsection{Open Space and Vegetation}

The use of vegetation in the outer space in front of the house, especially those directly adjacent to the sea, seems minimal. Even though the use of vegetation, namely in the form of trees, can reduce the temperature of the hot coastal air. Between the beach area and the house or building area on the beach there are still very few trees planted. Even if there is vegetation planted in front of the house, it is not vegetation with a strong coastal tree character and dense leaf volume that maximizes $\mathrm{CO} 2$ absorption. Whereas in the context of open space (open space) and city parks on Serangan Island, there is 1 city park, namely I Wayan Bulit Field and 3 open spaces next to TES Tsunami, to the east of Bugis and Graves Villages. The evaluation on the four open spaces is that there are no open space support facilities, namely the absence of toilets, communication devices, and warehouses to store food and medicines. Of course, if this open space functions as a disaster response room to support the TES Tsunami, it is better if the supporting functions of these public facilities are added. The amount of vegetation can be seen in 2 open spaces, namely I Wayan Bulit Field and the Grave. In fact, vegetation is a place for wild animals such as birds and insects. And when a disaster occurs, there is usually a natural change which is indicated by the behavior of these wild animals which seems to give an "alarm" to the local communit.

Meanwhile, in the area of investor ownership of PT. BTID is currently in the form of empty land. However, with the discourse on the construction of tourist facilities, of course in the context of architecture and disaster response environment, it is also necessary to plan the concept of evacuation and rescue of the community in the region. For this reason, it is recommended that the zoning for building laying be placed on the northwest side or the side farthest from the high seas. The zoning of this building is of course strived so as not to build residential facilities for overnight stays such as hotels, villas, and others because of course there is a risk of evacuation, especially at night when hotel residents are fast asleep. However, if staying overnight facilities are planned, each room should be equipped with loudspeakers for both hotel information and an alarm for an earthquake disaster accompanied by a tsunami threat. The number of buildings was strived to be small by providing vehicle and evacuation routes around the island and there are many shortcuts to TES Tsunami.
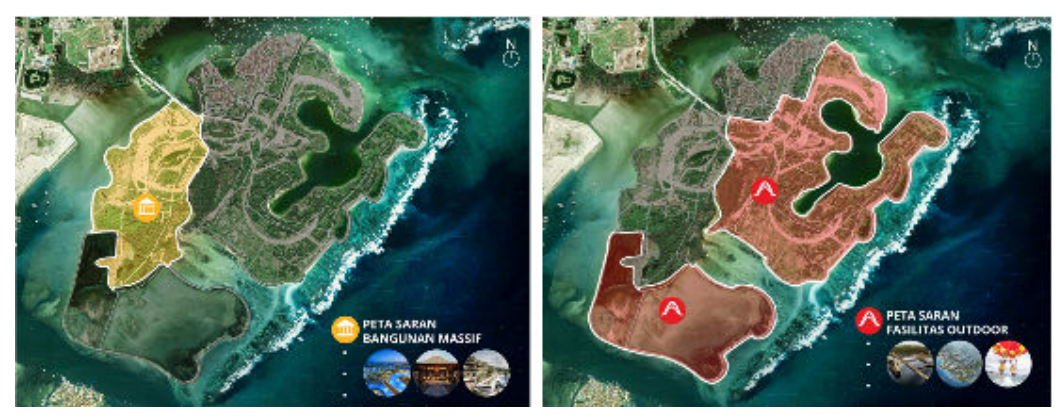

Figure. 10. Zoning Recommendation for The Placement of Buildings and Outdoor Facilities in The Ownership Area of PT. BTID

Meanwhile, the remaining land adjacent to and bordering the open sea on the southeast side, it is advisable to place outdoor facilities in the context of outdoor space and the absence of massive buildings except for monitoring towers. The recommended outdoor facilities are coastal tourism support facilities such as watersport facilities, fishing, mangrove tourism and 
their supporters. The purpose of only recommended outdoor facilities in this zone is so that tourists in this zone can see the high seas as a positive view as well as the threat of a tsunami disaster. In addition, with the absence of buildings, it causes tourists not to be too long in this zoning, especially staying in this zoning. Of course, vehicle and pedestrian lanes are equipped with complete disaster mitigation infrastructure such as vehicle and pedestrian evacuation routes, tsunami hazard alerts in strategic places and accelerated lanes that accelerate to evacuation sites and exit Serangan Island.

\subsection{Public Facilities in Disaster Response Settlements}

Public facilities found in the residential area of Serangan Island are quite complete, namely the existence of educational facilities in the form of elementary and junior high schools, religious facilities in the form of temples and mosques, trade facilities, namely markets, LPD and KUD, health facilities in the form of Puskesmas, security facilities in the form of TNI posts. Navy and Police Offices, Watersport facilities and Turtle Conservation Center, as well as other public facilities such as gas stations, sports fields and cemeteries. In the context of disaster response settlements, the placement of these public facilities is already in residential areas with scattered locations. All of these public facilities are already on major roads such as the Serangan Island ring road and roads that can be passed by cars, ambulances and damkar. With these conditions, it is possible for residents not to drive motorized vehicles to reach these public facilities. For example, the location of the puskesmas, police, village office and gas stations around the sports field which is used as a center for orientation and social activities for the people on Serangan Island. However, the completeness of public facilities in residential areas, especially in the field as a place for citizen interaction and sports venues in the context of daily functions and in the context of disaster mitigation, is somewhat incomplete. So the authors recommend the addition of public toilet facilities that can be used by the community on a daily basis. In addition, there is also a storage warehouse for First Aid equipment $(\mathrm{P} 3 \mathrm{~K})$ and buoys that can be used in disaster mitigation efforts.
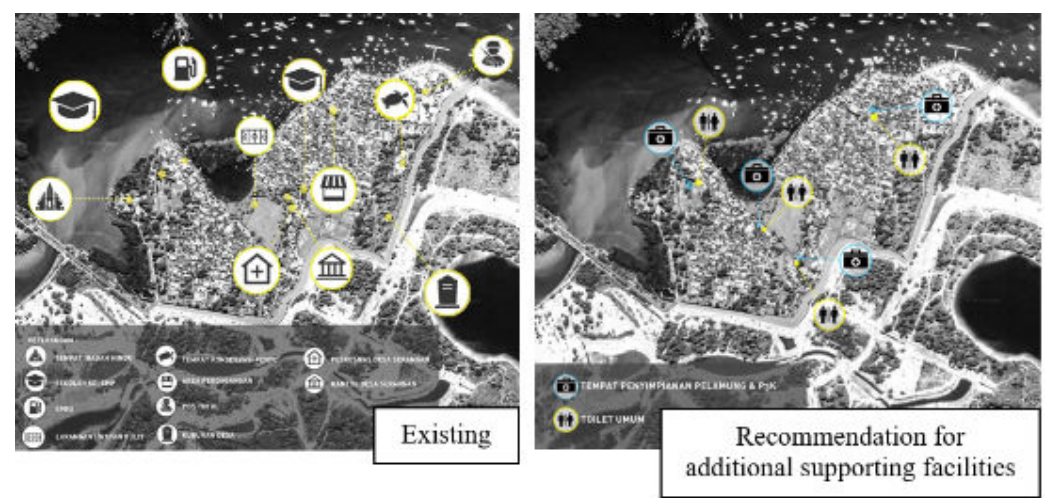

Figure. 11. Location of Public Facilities and Recommendations for Additional Tourism Support Facilities and Disaster Mitigation in Residential Areas 


\section{Conclutions}

The implementation of the Integration of the Concept of Disaster Response Architecture with the Concept of the Image of a Coastal Area on Serangan Island has mostly been applied to the coastal area, but there are some things that have not been implemented so that there are several recommendations for the design concept. The conclusion of the explanation is as follows:

- Escape Route, the absence of a special pedestrian path makes the recommendation for the design concept of a pedestrian path that surrounds Serangan Island, is above the existing retaining wall with the addition of wooden railings with complete evacuation directions on the railing and floor.

- Protected Area, placement of mangrove forest with the aim of being a greenbelt on the west side is wrong, it is recommended that the placement of mangrove forest is on the southeast side of the coastal area which is directly adjacent to the high seas, so as to reduce tsunami speed and give more time for tourists and residents to evacuate to the safe zone.

- Zona Aman, in residential areas, it is recommended that a new Tsunami TEST take place at SMP N 11 Denpasar to cover the evacuation of tourists and the people of Banjar Kubu and Kampung Bugis. Meanwhile in the investor area, PT. BTID recommended the placement of 2 TES Tsunami buildings integrated with tourist residential buildings on the northwest side or the side farthest from the high seas.

- Ruang Terbuka dan Vegetasi, it is advisable to place an open space as a tourist activity on the southeast side or adjacent and bordering the open sea which is the source of the tsunami disaster. It is not recommended that massive buildings on the southeast side be used as temporary shelters.

- Fasilitas Umum dalam Permukiman Tanggap Bencana, is fairly complete but needs to be maximized in the field with the addition of public toilets, buoys and first aid kits to accommodate disaster mitigation and tourism support.

\section{References}

[1] E. Purwanto, "Pendekatan Pemahaman Citra Lingkungan Perkotaan (melalui kemampuan peta mental pengamat)," DImensi Teknik Arsitektur, pp. 85-92, 2001.

[2] K. Lynch, "The Image of The City, " London: The MIT Press, 1975.

[3] A. H. a. S. S. A. Hilal, "Using NVIVO for Data Analysis in Qualitative Research," International Interdisciplimary Journal of Education, pp. 181-186, 2013.

[4] S. Almalki, "Integrating Qualitative and Qualitative Data in Mixed Methods ResearchChalenges and Benefits," J. of Education and Learning Vol. 5 No. 3, pp. 288-296, 2016.

[5] Afrizal, "Metode Penelitian Kualitatif, " Jakarta: Rajawali Pers, 2014.

[6] N. Hasanah, "Rentetan Bencana Alam di Indonesia Sepanjang 2018," 24 Desember 2018. [Online]. Available: https://nasional.okezone.com/read/2018/12/24/337/1995339/rentetanbencana-alam-di-indonesia-sepanjang-2018.

[7] T. Bali, "Eco Resort Serangan Sedot 50.000 Tenaga Kerja, Januari 2017 Genjot Pembangunan," 9 Desember 2016. [Online]. Available: 
http://bali.tribunnews.com/2016/12/09/eco-resort-serangan-sedot-50000-tenaga-kerjajanuari-2017-genjot-pembangunan?page=all.

[8] I. N. Sutarja, "Rencana Tempat Evakuasi Sementara (TES) Pada Kawasan Rawan Bencana Tsunami Provinsi Bali," Universitas Udayana, Denpasar, 2015.

[9] I. G. S. Darmawan, "Faktor-Faktor Pengaruh Perubahan Penggunaan Lahan Ulayat Akibat Reklamasi di Pulau Serangan," Undagi, vol. 6, pp. 37-44, 2018. 